\title{
TECHNOLOGY TRANSFER OF PUBLIC RESEARCH RESULTS (INCDMTM) TO THE PRIVATE SECTOR
}

\author{
Diana Mura Badea ${ }^{1}$, Valentina Bajenaru², \\ Dumitru Vlad 3 , Florin Teodor Tanasescu 4 , Mihaela Guda ${ }^{5}$ \\ 1,2,3 National Institute of Research and Development in Mechatronics and Measurement Technique \\ ${ }^{4}$ Romanian Electrotechnical Committee, \\ ${ }^{5}$ Ministry of Research and Innovation
}

\begin{abstract}
Finding proper ways to implement technology transfer is never easy. This is why all actors involved in R\&D must do more than just work hard on this issue. They must also be creative and find ways to approach this concept laterally. The tight competition asks for new ways of promoting results of the research work. Thus, this paper presents the way in which the research results of a national RDI institute can be transferred to the companies.
\end{abstract}

Keywords: Technology Transfer (TT); TT Guidelines; TT Centre.

\section{Introduction: Technology Transfer and the necessity of Technology Transfer GUIDELINES}

\subsection{Interest of the Romanian society and companies in Technology Transfer (TT) as driver of renewal}

There is a consensus in the Romanian society that technical progress can only be achieved by innovation and technology transfer of results from public scientific researches financed from government funds, which leads to an increased technical/economic potential of a company, thus increasing its chances to participate successfully in international exchanges.

SMEs in Romania are interested in the research activity, taking part in research programmes along with institutes and universities that address certain themes, the results of which solve some of the company's problems.

Informal transfer of knowledge, jointly prepared scientific works, access to laboratories intensify due to the fact that these actions often take place as a result of past collaborations or in the hope of future ones.

Companies in Romania are interested in the transfer of certain research results, but they do not have the necessary financial resources to buy the researcher's industrial property rights, nor the funds required to prepare for production and release of a product on the market.

The competition from foreign companies on the domestic market has determined Romanian companies to modernise their products to be competitive and, at the same time, to have access to markets abroad.

If this interest of Romanian companies in transfer exists, stimulating tools must be found for companies to be able to benefit of profitable loans, access to public/private capital funds, tax exemptions, state funding of some preliminary phases of Transfer, market surveys.

Equally, measures will need to be established to stimulate the interest of multinationals in Romania to finance innovation activities according to the company profile or to use Romanian patents that are applicable here. Currently, there are few examples of this kind, such companies working with the research centres of the parent company.

\subsection{Technology Transfer creates new jobs and staff skills}

Technology Transfer of certain public research results to companies comes along with increased company competitiveness and, consequently, increased number of jobs.

The establishment of spin-offs and start-ups based on marketing of patents is a new possibility to increase the number of jobs.

New jobs will also be created due to the services that may develop as a consequence of results transfer: market prospecting, benchmarking, services, vocational training etc.

The high technical level of such patents also leads to an increased professional level of employees, acquiring new technical abilities, higher technical training that allows industrial mobility. 


\subsection{Incentives for the researcher who transfers a result and for the company that uses it}

Unfortunately, neither the researcher, not the company are encouraged to transfer and to receive incentives.

Therefore, it is necessary to create rights for the two partners of the transfer, moral and financial incentives to increase the interest in promoting transfer. The state must not be excluded from the transfer of the research results to be financed from public funds and cannot be indifferent to what happens to the money spent.

The researcher has a moral responsibility for the research result for which $\mathrm{s} / \mathrm{he}$ was paid, and likewise, the company has the same responsibility to resist competition, to strengthen its position on the market and to ensure the stability of the workforce.

This paper proposes the creation of a new transfer mechanism, including development of specialised entities with transfer-related financial, legal and organisational power, with training in intellectual property issues to ensure the stimulation of the two partners in promoting technology transfer.

\subsection{Transferring more results means bringing more money for development in the financial circuit}

Although there is general consensus on the importance of research and its impact on the development of society, the Americans were the first to understand the importance of results transfer, both in terms of programming adoption and of the needs to recover incurred expenses.

Manhattan Project was the most obvious, then Silicon Valley.

If until 1980 the property right belonged to the inventor and transfer was made by its own weak efforts, ever since the issue of applying the industrial property right has been revolutionised in the sense that it was decided that institutions that had access to government funds should use the obtained results themselves, market them, organise specialised bodies and share the obtained benefits between the inventor and the institution.

Although apparently the state was at loss since it did not sell the patent/result, by the taxes charged on the productions made by this Transfer, the amounts received by the state were much higher!

It is also the reason why the paper presents the proposed technology transfer model and the organisation of such entities, resulting both in an accelerated transfer and a possibility to "return" to the budget a large amount of the expenses incurred with innovation.

\subsection{Foreign companies should be co- interested in the Technology Transfer of certain Romanian research results}

A solution could be to stimulate greater participation of these companies in National Research Programmes to solve their problems and other problems of interest, thus creating the framework of future transfer or a collaboration with the research sector in projects when they receive Romanian state aid.

\subsection{A model of research results dissemination in the mechatronic field to economic agents}

The development of an adequate model to transfer the results of the researches conducted by INCDMTM to the mechatronic and industrial sector must consider several important aspects starting first of all from the necessity to avoid the negative sides existing in the current system.

The main idea is that any system we may envisage, it must take into consideration:

- the specificity of our country (even if we intend to take some structural elements from certain highperforming European systems - see Fraunhofer, Steinbeis etc.);

- to use as much as possible the structure existing in the country in which funds and a lot of work have been invested;

- to bring pertinent amendments to improve and supplement the attributions of the institutions that will join the system, required to perform highquality transfer activities;

- the economy and industry development direction of our country to enable correct dissemination to those sectors and subfields that will be developed, a situation that we find in the strategy of highperforming systems in countries like Germany, USA, France etc. in which their economy sectors considered in the process of development are precisely outlined;

- to reinstate and improve the structural and institutional relations with some institutions that greatly contribute to supporting and performing technology transfer activities (OSIM, Chambers of Commerce, Local governments, Regional and national development agencies, SME Board);

- observance of European methodologies, in particular those that ensure better knowledge and extensive information between the sector that transfers the technologies and the economic and industrial sector, especially those related to patents, licences, models, tradenames, drawings etc.;

- supplementing the necessary staff and continuing vocational training thereof in all the units of the technology transfer system; 
- the reactivation of programmes to implement projects of institutional construction and technology services and to ensure proper financing;

- the need to finance technology transfer activities since such funding is currently inexistent, and if existing, it is supported from other means and with funds that do not ensure a substantive development of the issue. Such funding is necessary and mandatory since transferring entities need the funds to patent, licence and perform technology transfer activities, and the enterprises (existing or newly established) that use them need financing in order to buy the licences to start production with the new technology and to start earning money.

The proposed model involves a new vision and also a new approach based on the elements of the system existing in our country - MCI and ReNITT which can be structurally improved by some amendments, new attributions and improvement of those existing in their structure, from state financial aid of TT and from the own resources of the TT Centre, as a result of commercialising TT, as well as a revival of the activities provided in their operational status at different parameters. (In all countries in which Technology Transfer is consolidated, the preparation process of some TT, certain phases, are financially supported by the state).

\subsection{The Technology Transfer Centre now and in the future}

It is a very important entity in the ReNITT structure, with actual participation in the process of RD results dissemination to the economy and the industry.

We must emphasise once again that the entire transfer activity is coordinated, monitored and adjusted by ReNITT system via the Technology Transfer Centres (TTC).

These centres operate in Universities and National RD Institutions.

The Technology Transfer Centre can include the following:

- National and international members from the industry, research, academic environment, political representatives;

- Training team for the staff of the strategic partner and for the TTC staff financed through national funding mechanisms.

Depending of the requirements of each transfer stage, the TT Centre forms work teams that comprise:

- a TTC representative

- the holder of the technology (project, patent, exclusive rights etc.)

- specialists with training and expertise corresponding to the requirements of the stage, temporarily employed throughout the stage (stages) or the activity for which they were co-opted.
The attributions of these Transfer Centres ensure coordination and completion of all technology transfer stages, with the help of:

ReNITT Management, Institutions and central bodies (Ministry of Research and Innovation, Ministry of Economy, Ministry of Education, Ministry of Labour, Regional Development Agencies, Chambers of Commerce, National Board of SMEs, OSIM etc.), Entities attached thereto (Universities, RD Institutes).

Specialists in the field of the technology to be transferred, temporarily co-opted throughout the transfer stage (stages) or activity

Technology designer (holder of the project, patent, property right)

Partner (partners) chosen to use the technology.

In order to perform their attributions, the Technology Transfer Centres:

have operational and structural independence

have at least 3 employees, but they can also form multidisciplinary teams whose members must have at least 10 years of seniority in the field

in order to perform an activity with maximum output, they must not deal with more than 2 themes of technology transfer.

Thus, with this structural design, the technology transfer mechanism and all the undertakings required in the transfer activity flow take place between the two important players:

The Technology Transfer Centre, seconded in particular by the Technology Designer and supported by the entities listed above, as party that transfers the technology and

The strategic partner chosen, as party that receives the technology

The development of an adequate model to transfer the research results to the economic and industrial sector must consider several important aspects starting first of all from the necessity to avoid the negative sides existing in the current system. The main idea is that any system we may envisage, it must take into consideration:

- the specificity of our country (even if we intend to take some structural elements from certain highperforming European systems - see Fraunhofer, Steinbeis etc.);

- to use as much as possible the structure existing in the country in which funds and a lot of work have been invested;

- to bring pertinent amendments to improve and supplement the attributions of the institutions that will join the system, required to perform highquality transfer activities;

- the economy and industry development direction of our country to enable correct dissemination to those sectors and subfields that will be developed, a situation that we find in the strategy of highperforming systems in countries like Germany, USA, France etc. in which their economy sectors 
considered in the process of development are precisely outlined;

- to reinstate and improve the structural and institutional relations with some institutions that greatly contribute to supporting and performing technology transfer activities (OSIM, Chambers of Commerce, Local governments, Regional and national development agencies, SME Board);

- observance of European methodologies, in particular those that ensure better knowledge and more extensive information between the sector that transfers the technologies and the economic and industrial sector, especially those related to patents, licences, models, tradenames, drawings etc.;

- supplementing the necessary staff and continuing vocational training thereof in all the units of the technology transfer system;

- the reactivation of programmes to implement projects of institutional construction and technology services and to ensure proper financing;

- the need to finance technology transfer activities since such funding is currently inexistent. Such funding is necessary and mandatory since transferring entities need the funds to patent, licence and perform technology transfer activities, and the enterprises (existing or newly established) that use them need financing in order to buy the licences to start production with the new technology and to start earning money.

The pre-feasibility study proposes a pilot model involving a new vision and also a new approach based on the elements of the system existing in our country - MCI and ReNITT, which can be structurally improved by some amendments, new attributions and improvement of those existing in their structure, as well as a revival of the activities provided in their operational status at different parameters.

\section{Improved ReNITT structure}

With regard to ReNITT, this network preserves its current structural organisation, however with coordination at central level and specialised entities according to their specific attributions (Technology Information Centres, Technology Transfer Centres, science and technology parks, technology and business incubators).

These entities are implemented, as before, in universities, specialised RD institutes, various other RD entities, innovative SMEs etc.

However, the structure of these entities must be revised and reorganised, especially the structure of the Technology Transfer Centres with a view to provide them with professionally and numerically adequate staff, which will ensure continuous, correct and qualitative operation. In principle, the Technology Transfer Centres must be organised as follows:

\subsection{Weaknesses of the current Technology Transfer Centres in Romania}

It is painful to acknowledge this, but Technology Transfer of results from researches financed from public funds has rather a "voluntary" character, as the entity that receives public funds for research does not have an obligation and a responsibility to account for its contractual obligations. The TT Centres created in National Institutes or Universities are poorly sized in terms of their obligations (marketing, market surveys, intellectual property, legislation), have insufficient staff, since the funds for these activities come from other (reduced) resourced, the positive results - if any - owing to certain institute leaders with farsightedness. Effective operation of these TTCs will greatly depend on the concept that Romania will promote for Romania, the TT financing and efficiency, the legislation and the coercive/stimulating measures to be taken.

Among the most obvious weaknesses, the following must be pointed out:

The funds allocated to innovation are insufficient.

There are no funds for technology transfer activities.

In many cases the physical infrastructures for RD in laboratories are not demanded and, consequently, they do not have a concrete utility.

No ability of the TT centres of the ReNITT network to identify, centralise and forward TT demands to SMEs, local, regional or foreign centres

Inexistence of a data bank to record projects, patents and licences

Poor cooperation between the public and the private sectors

Low percentage of valorised patents

Results of projects, patents, inventions and licences are mostly theoretical and inapplicable.

No knowledge of the direction of development by economic and industrial sectors

Limited development of the industrial sector of SMEs and their technology level

Insufficient or very slow pace in the development of vocational training and management programmes.

\section{Conclusions}

\section{INCDMTM and Technology Transfer}

INCDMTM, by its Technology Transfer Centre CRTTC INCDMTM - pays special attention to the transfer of the results of scientific researches financed by the State, development of Companies and their increased competitiveness by High-Tech products specific to mechatronics, which is a priority of European research. 
Technology Transfer (TT) is the process by which the knowledge, products and technologies developed by public researches financed by the state are transmitted to companies to accelerate their progress and increase their competitiveness. The purpose of TT is to support the economy and to offer companies the opportunity to become as competitive as possible. Companies increase their competitiveness and economic strength, and research institutions acquire scientific strength and have the possibility to attract new funds for research and development.

Successful Technology Transfer implies that the two partners, the Company and the Public Institution join their forces to transfer a research result that may lead to the welfare of the society, their good collaboration depending on the efficiency of the transfer.

Technology Transfer does not mean just selling a patent; it comes along with all that scientific research can offer to a company: knowledge transfer, staff training, training sessions, joint projects and activities, access to laboratories and innovation platforms, technical assistance and services.

Technology Transfer takes place within entities specialised in TT that are established within the public research institute (INCDMTM or University), an entity with or without legal status, specialised in transfer, marketing and industrial property matters, and sized to perform a series of activities that will be documented in its organisation and operation regulations.

The implementation of a Transfer of knowledge usually takes place according to a certain TT scheme, but there can be also some specific phases for a certain application.

\section{References}

[1] ***Raport al Comisiei către Parlamentul European, Consiliu, Comitet Economic. Raport privind politica în mediul concurenţei pentru anul 2014 Com (2015) 247 final (4-6-2015)

[2] Sagasti F. Science Technology and Innovation Policy Instruments STPI: Background, Situation and Prospects. Key Note UNESCO, Paris oct. 19, 2011

[3] *** SR 13547-3 2012 Transfer Tehnologic. Principii generale şi linii directoare
[4] A Saitakis. INOVCRETE Technology Transfer and exploitation of Research Results. www.innovcrete.eu/files/1403/

[5] *** Chiffres cles de l'Europe Eurostat Livres statistiques Edition 2015

[6] *** The Choice of Innovation Policy Instruments. University Lund, Paper 2013/04

[7] *** Constituirea şi functionarea parcurilor industriale. Legea 186/2013

[8] M Anvret s.a: A new aproach to Innovation Policy in the European Union Bruxelles, CEPS UE, 2010

[9] K Debackere s.a: Open Innovation and Knowledge Transfer in the European Union. Bruxelles DGCI-UE, RTD Publications

[10] *** Strategia de dezvoltare a INCD-MTM 20162019

[11] Hakon Finne et al: A composite Indicator for Knowledge Transfer. Report from the European Comission's Expert Group on Knowledge Transfer Indicators. UE 2-011 - 10 - 15

https://ec.europe.eu/research/kti-report-final/pff

[12] Technology Innovation Centers: Applying Fraunhofer Model to create an effective Innovation Ecosystem in the UK

[13] Cr Grimpe, H Fler. Informal University Transfer. A comparison Between the United States and Germany. ZEW - Centre for Europeasn Economic Research, Paper 09-033.

[14] Abramson $\mathrm{N}$ et al: Technology Transfer in the United States and Germany. Lessons and Perspectives. Editor Fraunnhofer Institute for Systems and Innovation Research National Academy of Engineering, ISBN 0-309-52293-5, 1997. http://www.nap.edu/catalog/5271.html

[15] *** An Inventor's Guide to Technology Transafer at tje Massachusaette Instityute of Technology (MIT _ $\quad$ TLO) http://web.mit.edu/tlo/www

[16] Technology Transfer. Annual Report 2012. University of California http://www.upcop.edu/innovation_allianceservicxes/files/ott/genresources/

[17] $\mathrm{T}$ Posselt: Globalisation and Innovation. Strategie for value-creation. Lecture Fraunhofer at Indian Habitat Centre, New Delhi, 2012, 12.03.

[18] Benjamin Reid et all: Technology Innovation Centres: Applying the Fraunhofer model to create an effective Innovation Ecosystem in the UK, http://them.work.foundation.com/assets 